\title{
DERADIKALISASI TERORISME: Studi Atas Epistemologi, Model Interpretasi dan Manipulasi Pelaku Teror
}

\author{
Muhammad Nursalim \\ IAIN Raden Intan Lampung \\ m.nursalim@g.mail.com
}

\begin{abstract}
Abstrak
Fenomena terorisme marak diperbincangkan dan selalu menjadi isu hangat hingga kini. Terorisme sebagai aksi kekerasan untuk tujuantujuan pemaksaan kehendak, koersi dan publikasi yang memakan korban masyarakat sipil yang tidak berdosa, menunjukkan hubungan yang sangat erat dengan politik. Dalam perspektif filosofis, akar kekerasan muncul dalam fenomena identifikasi diri manusia ke dalam; "aku dan kamu" dan jauh lebih lagi kedalam "kita dan mereka". Identifikasi inilah yang selanjutnya menjadi akar lahirnya permusuhan yang berujung kekerasan. Untuk itu, perlu upaya deradikalisasi terorisme melalui epistemologi dan model interpretasi. Tulisan ini membahas aspek espistimologi dan interpretasi yang relevan dengan upaya deradikalisasi terorisme.
\end{abstract}

\section{Abstract}

DERADICALISED TERRORISM: THE STUDY OF EPISTEMOLOGY, INTERPRETATION AND MANIPULATION MODEL OF TERRORIST. Up to now, the phenomenon of terrorism has always been a lively discussion and a hot issue. In many cases, terrorism, as an act of violence for the purposes of the imposition of the will, coercion and publications, has a very close relationship with politics. Nevertheless, from a philosophical point of view, the roots of the violence can be traced in the phenomenon of human identification between "Me and you", and much more between "us and them". It is from such a phenomenon that hostility is born which, eventually, led to violence actions. Such a psychological explanation can be used to find alternative ways to suppress terrorism. In similar fashion, this article discusses some espistimological issues and interpretations relevant to the de-radicalization of terrorism efforts.

Kata Kunci: Deradikalisasi; Terorisme; Epistimologi dan Interpretasi 


\section{A. Pendahuluan}

Fenomena terorisme marak diperbincangkan dan selalu menjadi isu hangat sejak peristiwa 11 September di WTC, pengeboman Bali I dan II, hotel JW. Marriot dan Ritz Calten dan terakhir bom bunuh diri di Poso. Mereka ter mind-set dengan adanya kasus teroris yang terjadi pada kasus WTC 11 September 2001, bahwa terorisme berkaitan dengan fundamentalis agama Islam. Tentu saja, serangkaian tragedi pemboman ini merupakan pukulan dahsyat bagi Bangsa Indonesia.

Setelah kepemimpinan Presiden Soeharto berakhir pada Mei 1998, Indonesia memasuki periode transisi menjadi salah satu negara demokratis yang memiliki jumlah penduduk terbesar. Fakta tersebut dipilihnya pasangan Susilo Bambang Yudoyono dengan Yusuf Kalla sebagai Presiden dan Wakil Presiden melalui pemilihan umum yang paling demokratis sejak yang terjadi pada tahun 1955. Akan tetapi, masa reformasi ini juga ditandai dengan aksi kekerasan, demontrasi, dan bom di sejumlah kota di Indonesia.

Serangan bom yang dilakukan teroris merupakan sesuatu hal yang "baru" dalam politik Indonesia. Pada masa kepemimpinan Soeharto, khususnya dari pertengahan 70-an sampai menjelang jatuhnya, serangan teroris sangat jarang terjadi. Serangan bom meningkat sejak Mei 1998, terutama pada 2001, seperti terlihat dalam data berikut : dari Januari hingga Juli, sudah terjadi 81 peristiwa, sementara di ibukota Jakarta terjadi 29 peristiwa, dan selebihnya terjadi di luar Jakarta, seperti Depok, Bekasi, Yogyakarta, Banten dan Sulawesi Tengah (tidak termasuk Aceh dan Papua). ${ }^{1}$ Dari tahun ke tahun, ledakan bom makin meningkat Fakta tersebut seolah membenarkan teori dari Alberto Abadie yang mengatakan bahwa negara yang tengah mengalami masa transisi dari totalitarianisme menuju demokrasi ditandai dengan maraknya aksi-aksi kekerasan termasuk terorisme. ${ }^{2}$

${ }^{1}$ Sukawarsini Djelantik, Terorisme; Tinjauan Psiko-Politis, Peran Media, Kemiskinan, dan Keamanan Nasional, (Jakarta: Yayasan Pustaka Obor Indonesia, 2010), h. 2 .

${ }^{2}$ Alberto Abadie, Proverty, Political Freedom, and the Roots of Terrorism, (NBER Working Paper No.1085, Oktober 2004), h. 3. 
Terorisme sebagai aksi kekerasan untuk tujuan-tujuan pemaksaan kehendak, koersi, dan publikasi yang memakan korban masyarakat sipil yang tidak berdosa, menunjukkan hubungan yang sangat erat dengan politik. Aksi teror dan kekerasan seringkali dilakukan oleh kelompok-kelompok yang merasa dirugikan secara politik. Sudah banyak dibuktikan bahwa politik dan terorisme berhubungan satu sama lain. Jika arus komunikasi politik tersumbat, dalam arti media massa maupun sistem perwakilan rakyat tidak efektif dan tidak mampu memenuhi aspirasi rakyat, saat itulah terorisme muncul. Terorisme sama dengan perang, yaitu diplomasi melalui cara lain. Terorisme bersumber dari rasa ketidakpuasan dan frustasi politik. ${ }^{3}$

Terkait aksi terorisme ada dua yang menjadi pembahasan dalam makalah ini yaitu menyangkut kekerasan sebagai akibat dari tindakan terorisme dan pelaku teror. Pokok persoalan ini akan diuraikan dengan mencari epistemologi dari kekerasan, model interpretasi dan manipulasi pelaku teror.

\section{B. Epistemologi Terorisme}

Secara teoritis, Teror atau Terorisme tidak selalu identik dengan kekerasan. Terorisme adalah puncak aksi kekerasan, terrorism is the apex of violence. Bisa saja kekerasan terjadi tanpa teror, tetapi tidak ada teror tanpa kekerasan. Kekerasan adalah suatu tindakan yang ditunjukan kepada orang lain dengan maksud melukai, menyakiti dan membuat menderita baik secara fisik, maupun psikis. Terorisme merupakan pandangan yang subjektif. Oleh karena tidak mudahnya untuk membuat suatu pengertian tentang terorisme yang dapat diterima secara umum oleh semua pihak, maka pengertian paling otentik adalah pengertian yang diambil secara etimologis dari kamus dan ensiklopedia. Dari pengertian etimologis itu dapat diinterpretasikan pengembangannya yang biasanya tidak jauh dari pengertian dasar tersebut. Berikut akan dijabarkan beberapa definisi terorisme dari beberapa tokoh dan lembaga :

a. Menurut Muhammad Mustofa, Terorisme adalah tindakan kekerasan atau ancaman kekerasan yang ditujukan kepada sasaran secara acak (tidak ada hubungan langsung dengan

\footnotetext{
${ }^{3}$ Sukawarsini Djelantik, Terorisme; Tinjaua Psiko-Politik..., h. 4.
} 
pelaku) yang berakibat pada kerusakan, kematian, ketakutan, ketidakpastian dan keputusasaan massal. ${ }^{4}$

b. Juergensmeyer mengatakan Terrorism is meant to terrify. The word comes from the Latin terrere, to cause to tremble, and came into common usage in the political sense, as an assault on civil order, during the Reign of Terror in the French Revolution at the close of the eighteenth century ${ }^{5}$.

c. Departemen Luar Negeri AS, mendefinisikan bahwa terorisme adalah kekerasan yang direncanakan, bermotivasi politik, ditujukan terhadap target-target yang tidak bersenjata oleh kelompok-kelompok sempalan atau agen-agen bawah tanah, biasanya bertujuan untuk mempengaruhi khalayak. ${ }^{6}$

Meskipun sebuah aksi kekerasan dipandang di suatu negara sebagai aksi terorisme, tetapi mungkin tidak dianggap demikian di negara lain. Tipe-tipe kekerasan yang dibungkus terorisme dengan kekerasan jenis lain seperti tindakan kriminal biasa atau aksi militer pada waktu perang, masih memakai definisi ini.

Peneliti ilmu sosial mendefinisikan aksi teroris sebagai berikut; Kekerasan yang dikalkulasikan, dan ditujukan terhadap masyarakat sipil, termasuk personal keamanan dan militer yang tidak sedang bertugas, terjadi dalam kondisi damai, dan targettarget simbolis lainnya yang dilakukan oleh agen-agen rahasia, untuk tujuan psikologis yaitu mempublikasikan masalah politik, agama dan/atau intimidasi atau pemaksaan terhadap pemerintah atau masyarakat sipil agar menyetujui mereka. ${ }^{7}$

Definisi yang beraneka ragam dari berbagai perspektif dan motivasi tersebut menurut Laqueur sangat menyulitkan, untuk didapatkannya suatu pengertian yang substansial mengenai terorisme. Tidak ada defenisi terorisme yang mungkin dapat

${ }^{4}$ Muhammad Mustofa, "Memahami Terorisme: Suatu Perspektif Kriminologi”, dalam Jurnal Kriminologi Indonesia FISIP UI, Vol. 2, No. III, (Jakarta, Desember 2002), h. 30.

${ }^{5}$ Mark Juergensmeyer, Terror in the Mind of God: The Globa Rise of Religious Violence, (Los Angeles: University of California Press, 2000), h. 5.

${ }^{6}$ Erik S. Case, “Terorisme” dalam John T. Ishiyama dan Marijke Breuning (eds), Ilmu Politik Dalam Paradigma Abad ke-21; Sebuah Referensi Panduan Tematis Jilid 2, terj. Tri Wibowo BS, (Jakarta: Kencana Prenada Media Group, 2013), h. 191.

${ }^{7}$ Sukawarsini Djelantik, Terorisme...., h. 21. 
mencakup segala macam terorisme yang pernah terjadi sepanjang sejarah. Definisi semacam itu tidak ada atau diramalkan, tidak ada didapatkan di masa depan. ${ }^{8}$ Pesimisme Laqueur tersebut dikritik oleh Corlett melalui pernyataannya; Dengan alasan semacam ini tidaklah mengherankan jika Laqueur menyatakan, bahwa tidak ada harapan untuk mempertanggung jawabkan pemberian suatu teori umum tentang terorisme politik. Mengajukan alasan bahwa terorisme tidak dapat dipelajari sampai sebuah definisi ditemukan, merupakan suatu pernyataan yang tidak masuk akal. ${ }^{9}$

Perdebatan akademik definisi terorisme disebabkan oleh karena perbedaan cara pandang sehingga menghasilkan definsi yang berbeda, sehingga kitapun harus tahu geneologi terorisme.

Berkembangnya terorisme ditandai dengan bentuk fanatisme aliran kepercayaan yang kemudian berubah menjadi pembunuhan, baik yang dilakukan secara perorangan maupun oleh suatu kelompok terhadap penguasa yang dianggap sebagai tiran. Pembunuhan terhadap individu ini sudah dapat dikatakan sebagai bentuk murni dari terorisme dengan mengacu pada sejarah terorisme modern. Walaupun istilah teror dan terorisme baru mulai populer abad ke-18, namun fenomena yang ditunjukkannya bukanlah baru. Menurut Grant Wardlaw dalam buku Political Terrorism (1982), manifestasi terorisme sistematis muncul sebelum Revolusi Perancis, tetapi baru mencolok sejak abad ke-19. Dalam suplemen kamus yang dikeluarkan Akademi Perancis tahun 1798, terorisme lebih diartikan sebagai sistem rezim teror. ${ }^{10}$ Kata Terorisme berasal dari Bahasa Perancis "le terreur" yang semula dipergunakan untuk menyebut tindakan pemerintah dari hasil Revolusi Perancis yang mempergunakan kekerasan secara brutal dan berlebihan dengan cara memenggal 40.000 orang yang dituduh melakukan kegiatan anti pemerintah. ${ }^{11}$ Selanjutnya kata Terorisme dipergunakan untuk menyebut gerakan kekerasan anti pemerintah di Rusia.

${ }^{8}$ Walter Laqueur, A History of Terrorisme, (London: Transaction Publisher, 2001), h. 7.

${ }_{9}^{9}$ A.M. Hendropriyono, Terorisme: Fundamentalis Kristen, Yahudi, Islam, (Jakarta: Kompas Media Nusantara, 2009), h. 31-32.

${ }^{10}$ Muhammad Mustofa, Memahami....., h. 32.

${ }^{11}$ Rikard, Bangun, "Indonesia di Peta Terorisme Global", http;//www. polarhome.com, diakses 17 November 2010. 
Dengan demikian kata Terorisme sejak awal dipergunakan untuk menyebut tindakan kekerasan oleh pemerintah maupun kegiatan yang anti pemerintah. Terorisme muncul pada akhir abad ke-19 dan menjelang terjadinya Perang Dunia I, terjadi hampir di seluruh belahan dunia. Sejarah mencatat pada tahun 90-an aksi terorisme di Armenia melawan pemerintah Turki, yang berakhir dengan bencana pembunuhan masal terhadap warga Armenia pada Perang Dunia I. Pada dekade tersebut, aksi terorisme diidentikkan sebagai bagian dari gerakan sayap kiri yang berbasiskan ideologi, karena mereka percaya bahwa terorisme adalah cara yang paling efektif untuk melakukan revolusi politik maupun sosial, dengan cara membunuh orang-orang yang berpengaruh.

Kemudian setelah pasca Perang Dunia II, dunia tidak pernah mengenal "damai”. Berbagai pergolakan berkembang dan berlangsung secara berkelanjutan. Konfrontasi negara adikuasa yang meluas menjadi konflik Timur - Barat dan menyeret beberapa negara Dunia Ketiga ke dalamnya menyebabkan timbulnya konflik Utara - Selatan sehingga dapat membuat dunia bergejolak. Ketidakstabilan dunia dan rasa frustasi dari Negara Berkembang dalam menuntut hak-hakyang dianggap fundamental dan membuka peluang untuk muncul dan meluasnya terorisme. Fenomena terorisme meningkat sejak permulaan dasawarsa 70-an. Terorisme dan teror telah berkembang dalam sengketa ideologi, fanatisme agama, perjuangan kemerdekaan, dan pemberontakan. Bahkan juga terorisme oleh pemerintah dianggap sebagai cara dan sarana menegakkan kekuasaannya. Terorisme gaya baru mengandung beberapa karakteristik:

a. Ada maksimalisasi korban yang sangat mengerikan.

b. Keinginan untuk mendapatkan liputan di media massa secara internasional dengan cepat.

c. Tidak pernah ada yang membuat klaim terhadap terorisme yang sudah dilakukan.

d. Serangan terorisme itu tidak pernah bisa diduga karena sasarannya sama dengan luasnya seluruh permukaan bumi.

Polmer Situmorang menulis setidaknya ada 6 jenis tindakan terorisme yang dilakukan oleh kelompok teroris antara 
lain: ${ }^{12}$ a. Bombings/bom, b. Penculikan dan penyanderaan, c. Penyerangan dan pembunuhan bersenjata, d. Pembakaran dan pembumi hangusan, e. Pembajakan dan perompakan, dan $\mathrm{f}$. Jenisjenis kekerasan lain oleh terroris.

Dalam perspektif filosofis, akar kekerasan muncul dalam fenomena identifikasi diri manusia ke dalam: "aku dan kamu", dan lebih jauh lagi ke dalam "kita dan mereka". Indentifikasi inilah yang selanjutnya menjadi akar lahirnya permusuhan yang berujung kekerasan. Pelaku kekerasan biasanya melakukan tindak kekerasan terhadap korbannya, karena sebagai "sesama" manusia mereka lebih menonjolkan ke-aku-annya dan ke-kita-annya. Hal ini dimungkinkan terjadi, karena menurut Simmel (1995) manusia secara tak terhindarkan akan berhadapan dengan kondisi-kondisi epistemologis, yakni proses pengenalan manusia. Proses mengkamu-kan dan me-mereka-kan adalah proses pengasingan dalam pengenalan manusia sebagai sesama. "Kamu" dan "Mereka" dianggap asing, bukan hanya sekedar sebagai penduduk, warga negara atau pengikut sebuah kelompok, melainkan lebih dari itu asing sebagai manusia. Dengan kata lain, korban kekerasan didehumanisasikan dan didepersonalisasikan sampai pada status obyeknya. Ketika status obyek manusia lain didehumanisasikan dan dipersonalisasikan, menjadi sangat mungkin bagi manusia untuk mengkondisikan tindakan kekerasan terhadap Kamu dan Mereka ke dalam struktur pikiran manusia itu sendiri.

Secara filosofis, ideologi-ideologi para teroris yang menyerang menara kembar (WTC) dan pentagon mengeskplisitkan penolakan atas jenis modernitas dan sekularisasi yang di dalam tradisi filsafat diasosiasikan dengan konsep pencerahan. ${ }^{13}$ Dalam filsafat, pencerahan menggambarkan bukan hanya periode spesifik, yang secara historis bertepatan dengan abad ke 18, melainkan juga afirmasi atas demokrasi dan pemisahan kekuasaan politik dari kepercayaan keagamaan yang dijadikan fokus oleh Revolusi Perancis dan Revolusi Amerika.

12 Polmer Situmorang, Jenis-jenis Terorisme, ditulis padan tanggal 13 November 2009, 15:05, http//www.Polmersitumorang.bloger.com, diakses pada tanggal 20 Oktober 2010.

${ }^{13}$ Borradory Giovanna, Philosophy In A Time of Terror: Dialogues with Jurgen Habermas And Jacques Derrida, (Chicago: University of Chicago Press, 2003), h. xi. 
Selain itu, fenomena baru yang ditemukan dari penelitian terhadap terorisme, yang dikaji dari filsafat analitis bahasa adalah; di dalam bahasa terorisme terdapat kemiripan keluarga (family resemblance), sebagai analogi di dalam satu bentuk tata permainan bahasa yang sama. Hal ini berarti teori Wittgenstein II yang menyatakan, bahwa "Aneka Kemiripan Keluarga" terdapat di dalam berbagai bentuk tata permainan bahasa yang lebih dari satu, tidak berlaku dalam konteks terorisme. Para subyek yang melakukan terorisme sama-sama mengacu kepada Tuhan dalam melakukan kejahatan mereka. Hal tersebut tampak dari ungkapan yang terlontar: Semoga Allah meridai kita dan juga May God Bless Amerika. ${ }^{14}$ Hal tersebut berarti terorisme dilakukan oleh para subyek yang samasama merupakan individu-individu penganut agama. Penggunaan ungkapan bahasa yang baru mempunyai rule of the game tertentu yang baru pula ${ }^{15}$.

Bahasa yang digunakan dalam terorisme ternyata juga terbelah atas dua tata permainan bahasa, yaitu mengancam dan berdoa yang digunakan sekaligus. Tata permainan bahasa yang terbelah dalam terorisme tersebut menunjukkan, bahwa terorisme mempunyai kepribadian yang terbelah (split personality).

Komarudin berpendapat bahwa aksi radikalisme di Indonesia masih menjadi ancaman di tengah kehidupan masyarakat. Radikalisme yang ekstrim dilakukan melalui aksi bom bunuh diri yang dijustifikasikan sebagai tindakan jihad membela agama. Radikalisme pada dasarnya mempunyai makna netral bahkan dalam studi filsafat jika seseorang mencari kebenaran harus sampai kepada akarnya. Namun ketika radikalisme dibawa ke wilayah tetorisme maka radikalisme memiliki konotasi negatif. "Radikalisme memiliki makna militansi yang dikaitkan dengan kekerasan yang kemudian dianggap anti sosial". ${ }^{16}$

\footnotetext{
${ }^{14}$ A.M. Hendropriyono, Terorisme...., h. 434.

${ }^{15}$ Ludwig, Wittgenstein, Philosophical Investigations, translated by GEM, Anscombe, (Oxford: Basil Blackwell, 1983), h. 23.

${ }^{16}$ Lihat "Komaruddin Hidayat: Perguruan Tinggi Berperan Mencegah Radikalisme” dalam Lazuardi-birru.blogspot.com/2012/12/komaruddin-hidayatperguruan-tinggi.html (akses, 18 Juni 2013).
} 


\section{Model Interpretasi Teroris}

Terorisme selalu identik dengan teror, kekerasan, ekstriminitas dan intimidasi sehingga seringkali menimbulkan konsekuensi negatif bagi banyak orang dan dapat menjatuhkan korban yang banyak. Sebagian para pelaku teroris di Indonesia menganggap dirinya sebagai mujahid fi sabilillah. Padahal Islam tidak mengajarkan yang demikian itu dan juga tidak mengajarkan kekerasan dalam menyebarkan ajaran Islam dan melaksanakan amar ma'ruf nahi munkar.

Relasi agama yang tidak hanya dengan perdamaian, tetapi juga kekerasan sangatlah sulit untuk kita tolak manakala kita menyaksikan bahwa agama seringkali digunakan sebagai landasan ideologis dan pembenaran simbolis bagi tindak kekerasan yang dilakukan sebagian umat beragama. Menurut Haryatmoko setidaknya ada 3 alasan mengapa agama memiliki kemungkinan untuk dijadikan landasan dan pembenaran tindak kekerasan. Pertama, adalah karena fungsi agama sebagai ideologi. Dalam fungsi ini agama kemudian menjadi perekat suatu masyarakat karena memberi kerangka penafsiran dalam pemaknaan relasi antar manusia, yakni sejauh mana tatanan sosial dianggap sebagai representasi religius, yang dikehendaki Tuhan. Lebih jauh fungsi perekat ini, disisi lain juga bisa menghasilkan banyak kontradiksi terutama menyangkut masalah ketidak adilan dan kesenjangan yang selalu menjadi topik yang panas dan acapkali melahirkan tindak kekerasan. Kedua, adalah fungsi agama yang juga sebagai faktor identitas. Agama secara spesifik dapat diidentikkan kepemilikannya pada manusia atau kelompok manusia tertentu. Kepemilikan ini memberi stabilitas, status, pandangan hidup, cara berpikir, etos dan sebagainya. Hal ini lebih mengkristal lagi bila dikaitkan dengan identitas lainnya seperti seksual (jenis kelamin), etnis (kesukuan), bangsa dan sebagainya. Pertentangan etis, kelompok, bangsa dan sebagainya sangat mungkin melahirkan kekerasan dan di sini agama sangat mungkin untuk turut diikutsertakan juga. Ketiga, fungsi agama sebagai legitimasi etnis hubungan antar manusia. Berbeda dengan agama sebagai kerangka penafsiran, mekanisme ini bukan sakralisasi hubungan antar manusia, tetapi suatu hubungan antar manusia yang mendapat dukungan dan legitimasi dari agama. 
Padahal orang tahu, di dunia apalagi dunia ketiga, ekonomi pasar sangat akomodatif terhadap rezim anti demokrasi, yakni represif terhadap gerakan kesetaraan dan biang dari kekerasan struktural. Dengan demikian potensi agama untuk diikut sertakan dalam tindak kekerasan sebagai 'landasan dan legitimasi' menjadi sangat memungkinkan. ${ }^{17}$

Selanjutnya, kekerasan atas nama agama bisa terjadi juga karena munculnya hubungan diantara keduanya yang ditandai oleh ambiguitas, yakni sifat mendua yang sangat nyata. Inilah yang kemudian melahirkan pepatah bahwa agama ibarat dua sisi mata uang yang bertolak belakang, sebagai sumber kedamaian; sekaligus sebagai sumber kekerasan dan konflik. Kalangan agamawan boleh saja mengklaim orientasi kepada kedamaian sudah intrinsik dalam tradisi dan ajaran agama-agama, tetapi secara intrinsik pula agama telah memancing dan melahirkan terjadinya konflik dan kekerasan. Mengenai yang terakhir ini, Ihsan Ali Fauzi menyatakan bahwa akar kekerasan teologis juga bisa bersifat internal dan eksternal. Untuk akar teologis internal, Ihsan menyebutnya sebagai kaum fundamentalis agama sedangkan akar teologis yang bersifat eksternal menurut Ihsan adalah kaum fundamentalis sekuler. ${ }^{18}$

Setiap pelaku teror selalu menghubungkan bahwa tindakan mereka termasuk jihad, dalam pandangan Muklas pelaku Bom Bali I, bahwa jihad hukumnya wajib. Adalah suatu keharusan untuk berjihad dan mengobarkan semangat jihad kepada umat Islam di seluruh dunia dalam melakukan perlawanan terhadap dominasi Amerika dan sekutunya bangsa Yahudi. Adapun jihad dengan aksi peledakan bom di tempat umum di Indonesia adalah ijtihad dirinya untuk melaksanakan tugas jihad. Dalam hal memilih, menimbang dan memutuskan, ia mencari dasar dari tindakan yang dilakukannya dari dalil-dalil al-Qur'an. Salah satu dari tujuan dan hikmah disyariatkannya jihad yang disitir dari Abdullah Azzam, menurutnya adalah untuk merendahkan, menghinakan musuh-musuh Allah dan meteror mereka dan menahan kekuatan

${ }^{17}$ Haryatmoko, “Agama: Etika Atasi Kekerasan”, dalam Harian Kompas, edisi 17 April 2000.

${ }^{18}$ Ihsan Ali Fauzi, Ambivalensi sebagai peluang; Agama, Kekerasan dan Upaya Perdamaian, 2005 dalam www.scripps.ohio.edu/new..diakses 20 Oktober 2013. 
mereka (QS. at-Taubah; 29, dan QS. al-Anfal; 60). ${ }^{19}$ Menurut Imam Samudra bahwa peledakan Bom Bali I adalah perwujudan dari jihad fi sabilillah. ${ }^{20}$ Ada beberapa potongan ayat al-Qur'an tentang perang di dalam buku "Aku Melawan Teroris"; QS.at-Taubah; 5, artinya... bunuhlah orang-orang musyrikin itu dimana saja kamu jumpa mereka, QS. at-Taubah; 14 yang artinya; "Perangilah mereka, niscaya Allah akan menyiksakan mereka dengan tangan-tanganmu”, selanjut QS. at-Taubah; 29, 36, QS. al-Anfal; 39 dan QS. al-Baqarah; 199.

Menurut Nasir Abbas, bahwa potongan ayat yang dicomot Imam Samudra sebagai perbandingan pengambilan dalil untuk dijadikan sandaran berhujah. Tentunya, akan terlihat perbedaan faham yang mencolok jika ayat-ayat al-Qur'an tersebut dipotongpotong lalu dijadikan alasan keyakinan. Mengenai QS. at-Taubah ayat 5 berhubungan dengan ayat sebelumnya (QS. at-Taubah; 4) dan sesudahnya (QS. at-Taubah; 6) tentang orang-orang musyrikin, yaitu mengenai orang yang melanggar perjanjian damai dan orang-orang yang setia dengan perjanjian damai. ${ }^{21}$

Dalam pandangan Safii Ma'arif bahwa bom bunuh diri itu jelas berdasarkan konsep teologi yang sangat kacau, sebab tidak ada alasan rasional sama sekali di belakangnya. Sesungguhnya praktik serupa juga dilakukan oleh pemeluk Hindu di India yang secara nekat telah membunuh Indira Gandhi, misalnya. Di Sri Langka, oleh gerakan kemerdekaan Macan Elam Tamil yang melawan pemerintahnya. Dari bermacam-macam sebab gerakan bunuh diri itu, ada kesamaan penyebab utama; frustasi, marah, dan putus asa menghadapi realitas yang dinilai semakin kejam dan tak teratasi. "Daripada hidup bercermin bingkai, lebih baik mati berkalang tanah," kata peribahasa. ${ }^{22}$

${ }^{19}$ Mirra Noor Milla, Mengapa Memilih Jalan Teror : Analisis Psikologis Pelaku Teror, (Yogyakarta : Gadjah Mada University Press, 2010), h. 140-141.

${ }^{20}$ Muhammad Hanif Hassan, Teroris Membajak Islam; Meluruskan Jihad Sesat Imam Samudra dan Kelompok Islam Radikal, (Jakarta: Grafindo Khazanah Ilmu, 2007), h. 12 .

${ }^{21}$ Nasir Abbas, Membongkar Jamaah Islamiyah; Pengakuan Mantan Ketua II, (Jakarta: Grafindo Khazanah Ilmu, 2009), h. 197-198.

${ }^{22}$ Ahmad Syafi'i Ma’arif, “Islam dan Bahaya Radikalisme Beragama”, Kata Pengantar, dalam Muhammad Hanif Hassan, Teroris Membajak Islam; Meluruskan Jihad Sesat Imam Samudra dan Kelompok Islam Radikal, (Jakarta: Grafindo Khazanah Ilmu, 
Konsep "jihad" dalam Islam menangkap spirit perang spiritual. "Perang Suci" adalah melawan diri sendiri. Jihad melawan nafsu yang tak terkendali, kurangnya disiplin spiritual, dan kecenderungan untuk melegitimasi kekerasan. Memerangi orang lain hanya situasional sifatnya. Di dalam dan di luar Islam, banyak perdebatan tentang pembenaran yang layak terhadap perang situasional ini, sarana dan tujuannya tantangan bagi mujahid damai Muslim adalah mempertahankan budaya agama yang menolak kekerasan sebagai alat menumpahkan keluhan atau mempertahankan hak-hak minoritas yang tertindas. ${ }^{23}$

Berkenaan dengan konsep jihad, Islam telah memberikan batasan dengan ketat. Bagi Islam, sifat dasar jihad adalah pembelaan diri atas kehormatan harga diri umat Islam. Bukan untuk menebar teror dan kebencian bagi warga sipil. Dalam khazanah fikih, jihad yang merupakan kewajiban komunal(fard al-kifayah), bukan kewajiban personal (fard al-ain) memiliki prasyarat yang sangat ketat. Salah satunya adalah bahwa jihad hanya dapat terlaksana setelah kepala pemerintahan memberikan perintah untuk jihad. Sayangnya, syarat ini selalu dilupakan oleh para pelaku teror yang menganggap aksi terornya sebagai salah satu bentuk jihad. Syarat kedua, pelaksanaan jihad baru bisa dilaksanakan setelah adanya peringatan terhadap pihak lawan.

\section{Manipulasi Pelaku Teroris}

Bagaimana psikologi memandang pelaku teroris? Teori psikologi secara spesifik mempertanyakan mengapa individu atau kelompok masyarakat begitu mudah tertarik bergabung dengan organisasi teroris. ${ }^{24}$ Teori-teori psikologi menjelaskan tentang aspek kejiwaan individu atau kelompok pelaku terorisme, yang meliputi proses rekruitmen, pengenalan, kepribadian, keyakinan, dan motivasi anggota jaringan terorisme. Melalui penjelasan psikologi akan diketahui latar belakang pelaku teroris, misalnya faktor

2007), h. xix.

${ }^{23}$ Zakiyuddin Baidhawy, Konsep Jihad dan Mujahid Damai (The Concept of Jihad and Mujahid of Peace), (Jakarta: Diktis Kemenag, 2012), h. 6-7.

${ }^{24}$ George Ritzer, Sociological Theory, (USA: The McGraw-Hill Companies, 1996), h. 402. 
teralienasinya (keterasingan) individu atau kelompok secara sosial, serta adanya motivasi politik dan agama. Bahkan berdasarkan analisis psikologi, dapat ditemukan fakta bahwa individu atau kelompok yang direkrut menjadi teroris tersebut adalah mereka yang mengalami gangguan dalam kepribadiannya. Mereka adalah sekelompok orang yang bermental sakit (mental illnes), sehingga berani melakukan perbuatan yang penuh resiko seperti bom bunuh diri.

Penyebab teror dari suatu tempat ke tempat yang lainnya mendapatkan perhatian kalangan akademisi pada awal dekade 80an seperti David G Hubbard yang melakukan pendekatan psikologis untuk menganalisa penyebab terorisme. ${ }^{25}$ Hubbard membahas tiga substansi yang diproduksi di dalam tubuh yang berada di dalam tekanan; norepinephrine, komponen yang diproduksi oleh kelenjar adrenal dan saraf simpatis dan berasosiasi dengan respon psikologis "fight atau flight" dari individu yang tengah berada dalam kondisi tertekan. Selanjutnya, ada acetylcholine, yang dihasilkan oleh saraf parasimpatetis dan aksi-aksi untuk meningkatkan respon norepinephrine, dan endorphins dalam otak sebagai respon terhadap tekanan dan membius otak, sehingga menjadi 100 kali lebih kuat daripada morphine. Karena substansi-substansi ini ada dalam diri teroris, maka disimpulkan bahwa kebanyakan kekerasan yang dilakukan teroris tidak berakar pada faktor kejiwaan, karena sebagian diakibatkan peniruan atas respon isu yang dipicu tekanan. Kesimpulan Hubbar menunjukkan bahwa menyebarnya terorisme disebabkan efek penyebaran (contagion effects). ${ }^{26}$

Oots dan Wiege mengatakan bahwa kondisi psikologis calon teroris secara signifikan dipengaruhi stabilitas masyarakat. Calon teroris terangsang melakukan aksi-aksi kekerasan karena pemberitaan media. Salah satu sikap kekerasan tersebut bersifat machiavellianisme karena teroris bertujuan memanipulasi korbankorban mereka seperti juga memanipulasi media, masyarakat, dan pemerintah. Para teroris mencatatkan bahwa calon teroris "hanya

${ }^{25}$ David G. Hubbard, "The Psychodynamics of Terrorism" dalam Yonah Alexander, T. Adeniran, R.A Kilmarx, eds, International Violence, (New York: Praeger, 1983), h. 45-53.

${ }^{26}$ Ibid., h. 17. 
perlu melihat bahwa terorisme telah bekerja untuk orang lain agar terdorong bersifat agresif". ${ }^{27}$

Banduradalampenelitiannyauntukmenghasilkanperbuatanperbuatan biadab dibutuhkan kondisi sosial yang kondusif dan bukan orang yang menyeramkam yang akan melakukan kekerasan. Dengan kondisi-kondisi sosial yang tepat, orang yang sopan dapat diarahkan untuk melakukan hal-hal yang luar biasa kejamnya. ${ }^{28}$ Hasil penelitian Bandura ini ternyata sesuai dengan fakta lapangan bahwa kita-masyarakat sering terkecoh atau kaget atas pelaku teror yang selama ini dikenal sopan, ramah dan tidak banyak persoalan.

Sedangkan Mirra Noor Milla dalam penelitian disertasi nya menyimpulkan bahwa; Identitas personal mereka melebur dalam identitas kelompok berdasarkan kelompok keagamaan, demikian juga dengan suku dan kebangsaan yang mereka miliki. Sense individualitas mereka melebur dalam kelompok, umat Islam secara keseluruhan di penjuru dunia. Penguatan identitas terjadi saat dipersepsi adanya ancaman yang ditujukan kepada kelompok mereka $^{29}$. Penganiayaan, pelecehan dan penyerangan terhadap umat Islam di berbagai dunia menyebabkan ancaman tersebut terasa nyata yang memperoleh justifikasi dari ayat-ayat dalam al-Qur'an untuk menguatkan keyakinan mereka.

Terorisme dilakukan oleh kelompok-kelompok yang telah mencapai keputusan secara kolektif berdasarkan keyakinan yang dipegang bersama walaupun komitmen setiap orang terhadap kelompok dan keyakinan tidak sama. Terorisme yang berorientasi politik melakukan tindakan politik secara perorangan atas nama bersama dan secara kolektif berusaha membenarkan tindakannya.

\section{E. Penutup}

Radikalisme dan terorisme merupakan sikap dan tindakan yang menakutkan bagi masyarakat. Terorisme terjadi karena cara

${ }^{27}$ Kent Layne Oots dan Thomas C Wiegele, Terrorist and Victim; Psychiatric and Physiological Approaches From a Social Science Perspective, Terrorism: An International Journal, 8, No.1, 1985, h. 1-32.

${ }^{28}$ Albert Bandura, "Mekanisme Merenggangnya Moral" dalam Walter Reich (eds) Origins of Terrorism: Tinjauan Psikologi, Ideologi, Teologi dan Sikap Mental, terj. Sugeng Haryanto, (Jakarta: PT RajaGrafindo Persada, 2003).

${ }^{29}$ Mirra Noor Milla, Mengapa....,h. 243. 
pandangyang sempit, interpretasi yang tidak utuh terhadap ayat-ayat al-Qur'an serta manipulasi pelaku teror. Apabila terorisme dibiarkan tumbuh maka bisa menganggu kehidupan berbangsa, beragama, dan bernegara. Untuk itu agar terorisme tidak berkembang maka diupayakan ;

1. Untuk mencegah radikalisme supaya tidak berkembang maka pemerintah harus meciptakan kualitas dan taraf pendidikan yang baik, kesejahteraan masyarakat, hukum ditegakkan secara benar, dan pemerintah berwibawa ${ }^{30}$.

2. Penguatan identitas dan kohesivitas kelompok ditemukan memiliki kontribusi yang relevan dalam bias proses pengambilan keputusan peledakan bom sebagai jihad. Keputusan itu lebih didorong oleh motivasional dan bukan rasional, sehingga rekonstruksi skema kognitif tertentu berkaitan dengan jihad bukan menjadi pilihan utama dalam kegiatan counter-terorisme. Menurunkan kohesivitas kelompok dan identitas kelompok merupakan merupakan langkah awal yang bermanfaat dalam mengurangi kecenderungan dihasilkannya keputusan dalam kelompok yang lebih beresiko dalam relasi antar kelompok.

3. Peminimalan akses terhadap berbagai permaslahan dan informasi yang dapat digunakan sebagai justifikasi, di antara dua penilaian ketidakadilan terhadap kelompok yang disebabkan oleh penindasan dan penganiayaan, pengurangan ancaman terhadap kelompok, serta akses yang terbuka untuk berperan serta dalam struktur sosial dengan sistem yang beragam tanpa mengabaikan pemenuhan kebutuhan mereka akan identitas muslim yang integralistik, akan berguna dalam mengembalikan mereka dalam strategi yang moderat dalam relasi antarkelompok yang bersifat kompetitif tersebut ${ }^{31}$

4. Sedangkan Azyumardi Azra, menyampaikan solusi komprehensif terorisme ;

a. Melibatkan pendekatan sosio-kultural keagamaan memerlukan revitalisasi dan pemberdayaan pemberian kesempatan lebih besar dalam upaya solusi radikalisme dan terorisme. Dengan

\footnotetext{
${ }^{30}$ Komaruddin Hidayat, Perguruan Tinggi..., h. 25.

${ }^{31}$ Mirra Noor Milla, Mengapa..., h. 250-251.
} 
revitalisasi kepemimpinan ini, masyarakat bersangkutan dapat merajut kembali kohesi dan solidaritas sosial yang perlu untuk penguatan sistem dan mekanisme pencegahan dini dari infiltrasi anasir yang mengganggu pertahanan diri mereka.

b. Pembedayaan sosio-ekonomi masyarakat bersangkutan, khususnya remaja dan pemuda yang memang sangat rentan terhadap infiltrasi gagasan dan praksis radikalisme dan terorisme. Pendekatan ini dapat jadi langkah efektif mencegah terjerumusnya warga muda bangsa ke dalam tindakan merusak diri sekaligus negara-bangsa. ${ }^{32}[]$

\section{Daftar Pustaka}

Abadie, Alberto, Proverty, Political Freedom, and the Roots of Terrorism, NBER Working Paper No.1085, Oktober, 2004.

Abbas, Nasir, Membongkar Jamaah Islamiyah; Pengakuan Mantan Ketua II, Jakarta; Grafindo Khazanah Ilmu, 2009.

Alexander, Yonah, T. Adeniran, R.A Kilmarx, eds, International Violence, New York: Praeger, 1983.

Azra, Azyumardi, “Solusi KomprehensifTerorisme”, Jakarta :Kompas, Jum'at 14 Juni 2013.

Baidhawy, Zakiyuddin, Konsep Jihad dan Mujahid Damai (The Concept of Jihad and Mujahid of Peace), Jakarta: Diktis Kemenag, 2012. Ritzer, George, Sociological Theory, USA: The McGraw-Hill Companies, 1996.

Bangung, Rikard, "Indonesia di Peta Terorisme Global", http;//www. polarhome.com, diakses 17 November 2010.

Borradory, Giovanna, Philosophy In A Time of Terror: Dialogues with Jurgen Habermas And Jacques Derrida, Chicago: University of Chicago Press, 2003.

${ }^{32}$ Azyumardi Azra, "Solusi Komprehensif Terorisme", Harian Kompas, Jum'at 14 Juni 2013. 
Djelantik, Sukawarsini, Terorisme; Tinjaua Psiko-Politis, Peran Media, Kemiskinan, dan Keamanan Nasional, Jakarta: Yayasan Pustaka Obor Indonesia, 2010.

Fauzi, Ihsan Ali, Ambivalensi sebagai peluang; Agama, Kekerasan dan Upaya Perdamaian, 2005 dalam www.scripps. ohio.edu/new. diakses 20 Oktober 2012.

Harian Kompas, edisi 17 April 2000.

Hassan, Muhammad Hanif, Teroris Membajak Islam; Meluruskan Jihad Sesat Imam Samudra dan Kelompok Islam Radikal, Jakarta: Grafindo Khazanah Ilmu, 2000.

Hendropriyono, AM., Terorisme: Fundamentalis Kristen, Yahudi, Islam, Jakarta: Kompas Media Nusantara, 2009. Wittgenstein, Ludwig, Philosophical Investigations, translated by GEM, Anscombe, Oxford: Basil Blackwell, 1983.

Hidayat, Komaruddin, "Perguruan Tinggi Berperan Mencegah Radikalisme".lazuardi-birru.blogspot.com/2012/12/ komaruddin -hidayat-perguruan-tinggi.html. akses, 18 Juni 2013.

Ishiyama, T. John dan Marijke Breuning (ed), Ilmu Politik Dalam Paradigma Abad ke-21; Sebuah Referensi Panduan Tematis Jilid 2, terj. Tri Wibowo BS, Jakarta: Kencana Prenada Media Group, 2013.

Juergensmeyer, Mark, Terror in the Mind of God: The Globa Rise of Religious Violence, Los Angeles: University of California Press, 2000.

Jurnal Kriminologi Indonesia FISIP UI, vol 2 no III, Desember 2002.

Laqueur, Walter, A History of Terrorisme, London:Transaction Publisher, 2001.

Milla, Mirra Noor, Mengapa Memilih Jalan Teror : Analisis Psikologis Pelaku Teror, Yogyakarta: Gadjah Mada University Press 2010.

Oots, Kent Layne dan CWiegele, Thomas, Terrorist and Victim; Psychiatric and Physiological Approaches From a Social Science Perspective, Terrorism:An International Journal, 8, No.1, 1985.

Reich, Walter (eds) Origins of Terrorism: Tinjauan Psikologi, Ideologi, Teologi dan Sikap Mental, terj. Sugeng Haryanto, Jakarta: PT Raja Grafindo Persada, 2003. 
Situmorang, Polmer, Jenis-jenis Terorisme, ditulis padan tanggal 13 November 2009, 15:05, http//www.Polmersitumorang. bloger. com, diakses pada tanggal 20 Oktober 2012. 